IRA-International Journal of Education \&

Multidisciplinary Studies

ISSN 2455-2526; Vol.15, Issue 02 (May 2019)

Pg. no. 46-61.

Institute of Research Advances

http://research-advances.org/index.php/IJEMS

\title{
Communication Barriers Caused by Cultural Differences in Interpreting and Coping Strategies
}

\author{
Xinyi $\mathrm{Xu}^{1} \&$ Chuanmao Tian ${ }^{2 \#}$ \\ ${ }^{1,2}$ School of Foreign Studies, Yangtze University, Huibei, 434023 P.R. China.
}

\#corresponding author.

Type of Work: Peer Reviewed

DOl: http://dx.doi.org/10.21013/jems.v15.n2.p1

How to cite this paper:

Tian, C., Xu, X. (2019). Communication Barriers Caused by Cultural Differences in Interpreting and Coping Strategies. IRA International Journal of Education and Multidisciplinary Studies (ISSN 2455-2526), 15(2), 46-61.doi: http://dx.doi.org/10.21013/jems.v15.n2.p1

(c) Institute of Research Advances.

This work is licensed under a Creative Commons Attribution-Non Commercial 4.0 International License subject to a proper citation to the publication source of the work.

Disclaimer: The scholarly papers as reviewed and published by the Institute of Research Advances (IRA) are the views and opinions of their respective authors and are not the views or opinions of the IRA. The IRA disclaims of any harm or loss caused due to the published content to any party.

Institute of Research Advances is an institutional publisher member of Publishers International Linking Association Inc. (PILA-CrossRef), USA. The institute is an institutional signatory to the Budapest Open Access Initiative, Hungary advocating the open access of scientific and scholarly knowledge. The Institute is a registered content provider under Open Access Initiative Protocol for Metadata Harvesting (OAI-PMH).

The journal is indexed \& included in WorldCat Discovery Service (USA), CrossRef Metadata Search (USA), WorldCat (USA), OCLC (USA), Open J-Gate (India), EZB (Germany) Scilit (Switzerland), Airiti (China), Bielefeld Academic Search Engine (BASE) of Bielefeld University, Germany, PKP Index of Simon Fraser University, Canada. 


\section{ABSTRACT}

The paper is made up of five parts. The introduction part describes the background and fundamental structure of the paper. The second part is a review of the literature, which summarizes the views of previous studies and then adds some of our own viewpoints at the same time. The body part can be divided into two sections: analysis on the causes and forms of communicative obstacles; analysis on coping strategies of communicative disorders. The analysis of causes includes specific causes and specific problems. The coping strategies include how to make flexible use of interpreting strategies, how to make effective use of interpreting methods and how to enhance interpreters' awareness and competence of intercultural communication. The last part is the conclusion. Besides drawing on the views of previous studies, we also put forward our own points of view: one is putting the knowledge into practice can enhance the professionalism and ability of interpreters, the other is that domestication and foreignization are translation strategies, while literal and free interpretation are concrete methods of translation.

Keywords: interpreting; cultural difference; communication barrier; coping strategy

\section{Introduction}

\subsection{Research Motivation}

With the constant improvement and advancement of China's economy, science and technology, the cultural communication between China and the West have taken a giant step forward and become increasingly frequent. Over and above the fundamental component of culture, language is also deemed as one of the most important means of the embodiment of culture. It can be said that language plays an extremely crucial role in cultural exchange, which makes interpreting become more popular than before. Interpreting activity is both a linguistic activity and a means of cultural exchange and dissemination. However, a series of factors, such as cultural differences from country to country or between China and the West, have created barriers to communication in interpreting activities. In order to ensure the smoothness in the progress of interpreting activities, it is particularly important to enhance the interpreters' awareness and competence of intercultural communication. Therefore, how to make interpreters avoid communication barriers caused by cultural differences in interpreting activities is the main point waiting to be settled in the whole paper.

\subsection{Introduction to the Relationship between Interpretation and Culture}

Interpretation is classified as a kind of translation activities. It's an activity that expresses language in a verbal way and transfers information. Interpretation is an activity of cultural communication between the two countries. Due to the fact that interpretation involves different cultural backgrounds both in China and the West, there is no denying that only by understanding Chinese and Western cultures can we ensure the smoothness of interpreting activities. To introduce the connection between culture and interpretation, one must mention the relationship between intercultural awareness and interpretation. At present, the research on cross-culture awareness in interpreting activities between China and the West is at the stage of development. The researchers studied the connections between interpreting activities and culture from different aspects and put forward different views on coping strategies. Kirchhoff proposed that in the process of translating source language information based on the source language culture, it is necessary to consider the communicative needs of the recipient of the target language (Kirchhoff2002). Hu Wenzhong did some researches on language pedagogy combined with the needs of foreign language teaching (HuWenzhong1993: 2-5). Linda Beamer and Iris Varner (2003), for the first time, combined cross-cultural communication theory with business practice, using a large number of examples to roundly discuss the cultural characteristics and the differences in communication methods of different regions. With regard to this paper, the co-authors put forward some standpoints based on summarizing previous research 
achievements.

\subsection{Introduction to the Communication Barriers Caused by Cultural Differences}

Communication obstacles caused by cultural differences are mainly divided into two parts: information vacancy and pragmatic failure. There are mainly two types of information vacancy: language vacancy and cultural vacancy. For details, language vacancies include linguistic vacancies and verbal vacancies. Linguistic vacancies manifest in the following three aspects: vocabularies, grammatical vacancy and rhetorical vacancy. Verbal vacancies include complete vacancy, partial vacancy, compensating vacancy. In addition, cultural vacancies prevailingly consist of three types: national psychological vacancy, communicative vacancy and cultural vacancy. This paper mainly studies the cultural vacancy. Based on the research results of previous scholars, we can define the cultural vacancy that, on account of the differences in geographical conditions, historical backgrounds, social customs, religious and ideology of all ethnic groups, the concepts and phenomena in one language and culture are different from those in other languages. One language is unable to find the corresponding or similar expressions from the other, resulting in the formation of the language and cultural vacancies. Pragmatic failure refers to the communication misunderstandings or errors without achieving the desired result caused by improper ways of speaking and different expression habits from different countries, rather than the performance errors made in the ordinary use of words and sentences. In the course of interpreting, the pragmatic failures are mainly caused by the following three reasons: inappropriate topic selection; lack of understanding of the Chinese and Western culture and values; differences in salutation. To sum up, in the following parts, the following questions need to be researched on and solved:

1) What are the differences between Chinese and Western culture?

2) What are the communication barriers caused by cultural differences in in interpreting activities?

3) What should the interpreters do to deal with communication obstacles?

4) What is the practical significance of studying this topic?

\section{Literature Review}

\subsection{Chinese and Western Cultural Differences}

Cultural differences between China and the West include many aspects: differences in historical and cultural backgrounds, differences in value systems, differences in religious beliefs, differences in thinking patterns and so on. These differences have brought obstacles to cross-cultural exchange activities. Li Zhi proposed that cultural differences refer to the unique historical and cultural forms, traditional customs, lifestyle, literature, art, patterns of behaviour, thinking structure and values formed in the long-term process of social development and people's production and living (Li2014:111-112+125).

Differences in thinking patterns lead to differences both in the forms and contents of languages in interpretation. Just as Feng Weilan once said that the unique mode of thinking of all ethnic groups has created its unique method of language expression. The Chinese pays attention to the perception and subtlety of language, whereas Westerner emphasizes the formalization and structuralization of language (Feng 2009: 13).

Differences in historical and cultural forms increase the difficulty in disseminating accurate information in the process of interpretation. ZhongYingxiang proposed that different countries and nationalities have created objective conditions for producing different customs and cultures. The different cultural forms have added some difficulties to British and American literary translators (Zhong2017: 15). 


\subsection{Communication Barriers Caused by Cultural Differences}

Communication barriers caused by cultural differences between China and the West mainly include two aspects: cultural vacancy, pragmatic failure. The formation of these two major obstacles is inextricably linked with vocabulary. Although the vocabulary in the translation is a very small element, it reflects the cultural connotation of an article more often than not. Hu Wenzhong (1993:10) mentioned that the meaning of vocabulary is enlarged or narrowed during a long period of use, while some of the words are often used in some occasions, and gradually accumulated associative meaning, which is known as cultural connotation. When it comes to vocabulary, we must mention semiotics. Saussure, the founder of modern linguistics, founded semiotics. He defined language as a symbolic system of ideas - a hierarchical system of phonetics, vocabulary, syntax, texts, and more (cited in Zhang Yan2002:57-60). According to Liu Zhongning and Ma Yumei, Saussure set forth semiotics in his book that "language is first and foremost a system of signs, so we must resort to semiotics."(Cited in Liu\& Ma2015:46) As individuals who communicate with each other and want to understand what they want to express, they must translate what they want to make others convey into linguistic signs and then use these signs to convey information. Then it comes to cultural encoding and cultural decoding. That is, the speaker and listener encode and decode the language symbols according to certain rules so that the communication between them is clear and understandable and conforms to the language habits of both sides. Therefore, the correct use of linguistic signs in cross-cultural communication activities is conducive to solving communication barriers.

However, encoding rules and decoding rules are different in different countries. Take the East and the West, for example, Oriental people and Westerners are completely different in thinking mode, time concept and so on. Therefore, in the exchange of the two cultures, we must grasp both the rules of encoding and decoding. That is to say, we must understand the meaning expressed by the other's language signs in order not to cause out-of-order communicative errors (ibid.: 47).

\subsection{Domestication and Foreignization Strategies}

For a long time, researchers have put forward many different opinions on the issues of domestication and foreignization. With the development of translation in the fields of theory as well as practice, the debate over whether the two are antagonistic or complementary still exists. For now, naturalization and alienation are complementary to each other. Domestication is a translation strategy getting closer to readers, which means diluting the exotic features of the language, localizing the language and making it consistent with the reader's habitual expression. Foreignization is a translation strategy closer to the author, which means retaining the characteristics of foreign culture and making it consistent with the way in which the source language is expressed. Different researchers have different opinions on the advantages and disadvantages of both.

Wei Lin thinks that domestication helps translators to avoid the cultural conflicts and various forms of misunderstanding when translating the source language into the target language, so as to commendably convey the meaning of the source language culture to the target language readers (Wei 2016: 52-53). While Venuti (1995:4) gives domestication and foreignization such a definition that domestication translation is cultural embezzlement of the source language text. It is a manifestation of cultural colonialism. However, foreignization can respect the source language culture, resist ethnocentrism and racism and curb cultural hegemony. Wang Lei mentioned that foreignization can not only promote cultural exchanges as well as reduce cultural differences, but also avoid some cultural conflicts and promote the integration of Chinese and Western cultures (Wang2017: 74). 
Domestication and foreignization are two aspects of translation strategies. We should view the relationship between the two in a specific, dialectical and comprehensive way. Although different researchers hold different views on the two, it is undeniable that both domestication and foreignization are effective translation strategies, and neither can be completely replaced by another.

In short, when adopting the foreignization strategy, we should pay attention to the limit and the sense of propriety. When it does not work, we must resort to domestication. Anyway, the two strategies are complementary to each other.

\subsection{Enhancing Interpreters' Cross-Cultural Communication Skills}

As interpreting activities become increasingly diversified, the requirements for interpreters have also been raised. How to enhance intercultural consciousness of interpreters, overcome communicative obstacles in communication and improve the quality of cultural exchange and dissemination are issues that we are facing and in urgent needs of the solution.

Cultural exchange requires a variety of methods and models (GuoJianzhong1998:13-20). By studying some of the previous researchers' viewpoints, we have concluded that in the process of cultural communication and dissemination, interpreters should do as follows:

1) Further research on the culture of source and target languages;

Some awkward situations in the process of interpreting are often caused by the lack of a deep understanding of bilingual cultural differences in addition to the lack of language skills (ZhongZaiqiang2006: 63-65).

2) Flexible use of domestication and foreignization strategies;

The translated "finished product" does not have to be bound or shackled by the original words in terms of word selection, word order, sentence structure, or the use of the image(Huang Zhenyu2001: 68-72).

3) To learn professional knowledge and train interpretation skills in depth.

\subsection{Summary}

In the 21 st century, under the general trend of economic globalization, interpreting has become an indispensable way of cultural exchange and dissemination. China's interpreting work has also taken a new level with the continuous development of the economy. However, because of cultural differences and other factors, there are still many obstacles in interpreting activities. Therefore, it is the primary task of the thesis to find out the ultimate causes of obstacles and propose effective solutions to deal with them. After summarizing and analyzing, it is concluded that helping to improve intercultural communicative competence of interpreters is the basic content and the top priority of coping strategies. During the process of interpreting, interpreters should fully take the linguistic and cultural characteristics of both languages into account when solving linguistic problems such as vocabulary, word order and grammar. At the same time, interpreters should draw on the interpreting skills concluded by the predecessors in order to achieve the unity of literal meaning and connotation in interpreting.

\section{Causes and Forms of Communication Barriers in Interpreting}

Interpretation is a form of translation in which words are spoken verbally, messages are disseminated accurately, and one language is translated into another effectively. Different languages have different cultural connotations, and specific languages reflect and represent specific cultures. If the cultural background of language information is not able to be correctly understood during the process of interpretation, it will cause misunderstanding and 
even affect the quality of interpretation. Therefore, cultural differences to some extent is the fundamental cause of communication barriers.

\subsection{Chinese and Western Cultural Differences}

With the ever-increasing frequency and depth of cultural communications between China and the West, more and more communicative activities have taken place under the cross-cultural background. Cultural differences between the two sides have also gradually become evident. It is principally shown in three aspects: differences in historical backgrounds, differences in values and differences in modes of thinking. These cultural differences form a cultural barrier to communication activities.

Cultural differences refer to the differences in historical backgrounds, traditional habits, thinking modes and behavioural patterns of communicators in cross-lingual communication. In the process of cultural exchanges, both sides verbalize their thoughts and feelings according to their own thinking modes and cultural backgrounds. Therefore, the cultural connotations of corresponding utterances are different. In addition, they lack the necessary understanding of the cultural backgrounds of both parties, which ultimately leads to different views and even conflicts between the two sides in terms of communication, understanding and agreement. Next, we will discuss three aspects.

\subsubsection{Differences in Historical Background}

The historical background consists of two parts: the natural background (geographical environment) and cultural background (cultural environment).

Ancient China is in a closed environment - it is surrounded by Greater and Lesser Khingan Mountains in the east, the Qinghai-Tibet Plateau in the west, the Inner Mongolian Plateau in the north and the sea in the south. Because of the limited navigation skills at the time, it was hard for people to sail on the ocean with high winds and waves. Therefore, Chinese culture is relatively reserved and introverted. On the contrary, western culture originated in ancient Greece, which is located in the eastern Mediterranean. With unique marine resources, it is a maritime country made up of many islands. In ancient Greece, people could not find open plains and fertile land, but small stretches of land divided by rolling hills and passing rivers. Therefore, Western culture is relatively wild and unrestrained.

Certain geographical environment affects certain regional culture, Chinese culture originated in the land, and there exists a long-term development of small-scale peasant economy, so the land is of extraordinary significance for the Chinese. As Li Xing shows, there are many Chinese terms for "earth”, such as“土生土 长”(locally born and bred) and“土崩瓦解”(to collapse like a house of cards). If the interpreter translates “earth” word by word, it will make British and American confused (Li2009: 158). Conversely, Western culture originated in the oceans, and Westerners have a rich history of navigation. For example, the Great Sailing Era (the Age of Exploration) from the 15th century to the 17th century made the exchanges between continents in the world begin to be more frequent, so in English, there are many expressions of "sea". As Li Xing said, you cannot translate “all at sea" literally into“在海上” as the extended meaning of the phrase is “dazed and perplexed"(ibid.: 159).

The language contains an abundant and intensive cultural background. We all know that Chinese culture is profound. Take the different symbolic meanings of basic colour terms between China and Western countries for 
example - Color words pursue the symmetry of original meaning and associative meaning. That is to say, in different cultural backgrounds, the colour words that represent the concrete objects in China and the West contain their own different symbolic meanings. In China, people have special feelings about "red", and red has multiple meanings - 1 . Red symbolizes good luck. For example, in the traditional wedding ceremony, the bride and groom are wearing red suits; in the Spring Festival, each household's door should be hung with red lanterns and elders hand the red packet to the younger generation. 2. Red represents success. In ancient times, people who were trusted and favoured by their superiors were called “红人”, now called“当红”. 3. Red is a symbol of beauty, since the ancient regard beautiful woman as “红颜”. In Western culture, red is often linked up with "fire", "blood", "catastrophe" and "war" because of different historical backgrounds. Such as - 1. bloody battle (血战): a red battle; 2. Fire disaster (火灾): red ruin; 3. Financial deficit (财政赤字): (be) in the red; 4. 18th and 19th-century British soldiers in red uniform are called "red-coat". Yellow is the other example. Yellow under the background of ancient Chinese culture symbolizes "the colour of the emperors", which was derived from the ancient Yin-Yang and Five Elements Theory. Yellow is the representative color of "earth" in the Five Elements, so that the connotation of it is "the colour of the emperors" not only reflects the ancient people's worship of the Earth God but also confirms the above-mentioned view that "the land is of extraordinary significance to the Chinese language". In the West, however, the symbolism of yellow is relatively complicated. Some people think yellow represents betrayal and mean. For example, in Da Vinci's famous painting The Last Supper, Judas, who was betraying Jesus, is coloured yellow to indicate it. Yet some people hold different viewpoints, considering that the yellow symbolizes the holiness and supremacy. Because in the same picture, the Holy Grail used by Jesus is also coloured golden.

\subsubsection{Differences in Values}

Cultural value is another important aspect affecting intercultural communication. Values are often evinced as ethical values of a nation, and by subtle influences instil the standards of good and bad, positive and negative, beauty and ugliness, truth and falsity, which makes people realize what is learning, what to defend, what is worth their dedication to. Apparently, the value system is a set of "code of conduct for making choices and resolving conflicts"(Rokeach1968). A value system is the product of the long-term advancement of values. Value refers to people's judgment, perceptions and evaluations of object things and its' characteristics. There are many differences and disagreements in values between China and the West. For details, China advocates "collectivism". Under the influence of the ancient ideas of "Datong" (大同), China emphasizes "ethics", advocating "unity" and "dedication", and pursued the realization of the spirit. Collectivism as the core value of contemporary China is not accidental. It is a consistent continuation of the Chinese collectivist way of thinking for thousands of years. Its core is the emphasis on collectives as the main body of value, individual consciousness for collective consciousness and collective interests above personal benefit. These concepts are not difficult to see from the ancients' words. Confucius once said: "The supervisor man is broad-minded and not a partisan. The small man is a partisan and not broad-minded (君子周而不比, 小人比而不周)”, which means that the gentleman generally unites people instead of just being close to the minority, and vice versa. The sentence reflects the spirit of solidarity. Fan Zhongyan's "Be the first to bear hardships and the last to enjoy universal happiness (先天下之忧而忧, 后天下之乐而乐)” embodies the spirit of dedication. The West advocates "individualism", emphasizing the contractual rule of law, advocating personal liberty and pursuing material realization. "Individualism" is not a simple "egoism", but a complete system. Yao Xinzhong summarized three basic propositions in The Philosophy of Life between China and the West as follows: 1. All values are people-centred, that is, all values, though not necessarily created by men, are experienced by men. 2 . Individuals possess the highest level of value, while society is just a means and medium to serve personal 
purposes. 3. Everyone has equal rights and personal interests is above all else (Yao2001). That is to say, everyone is a self-restraint, self-containedand theoretically self-sufficient entity, and the community is only a collection of individuals. In addition, many literary works embody individualism. For example, from Jane Eyre, we saw thequality of independence and struggle of the heroine Jane Eyre; Hemingway's Old Man and the Sea embodies individual heroism and so on.

\subsubsection{Differences in Thinking Patterns}

The way of thinking is "the process of individual selection, evaluation and organization of external stimuli”(Singer1971: 69-72). In cross-cultural communication activities, only by understanding the thinking patterns of another culture can we further understand the language and behaviour of the culture. Oriental mode of thinking focuses on integrity and synthesis, but the Western mode of thinking emphasizes individuality and logicality. Affected by the "golden mean(中庸)" though, Chinese people are accustomed to implicit euphemism and are arc-thinking. For example, when they chat with people, they always have to make a few greetings before entering the topic. When praising, they should say modestly, such as "No, you praise me too much". And they would not open up the gift in front of others. Conversely, Westerners are used to directing expression, in other words, a straight line-thinking. They tend to go straight to the point and express an intuitive feeling about what they see.

The differences between Chinese and Western modes of thinking are reflected in many aspects, such as advertising terms. For example, the slogan of China Unicom(中国联通)—“情系中国结, 联通四海心(The Chinese knot, the united hearts)" reflects the Chinese focus on holistic thinking mode. However, the United States Nike shoes' advertising slogans, whether it is "Just do it" or "I dream" embodies the Western pursuit of individual freedom. China's ads also pay attention to the use of artistic techniques. For example, Buick Regal's slogan “心至, 行随, 动静合一(putting one's mind into action, a combination of motion and static)" reflects China's thinking mode focusing on educational meaning and beauty of sentences. Yet in America, Nestle coffee's slogan "The taste is great" just colloquially describes the taste of coffee, totally reflecting the Western direct thinking mode.

Differences in the way of thinking between the two sides are also reflected in their views on friends. Although "Circle Culture" is widespread both in Oriental and Western society, its meaning is different. Zuo Biao argues that the overall performance of Chinese culture is circular, that is, the overall orientation of the ring. "Attention should be paid to the harmony of group relations, the rate of group goals, and the maintenance of group interests." (Zuo2001: 68-72) Influenced by collectivism, Chinese circle of friends is comparatively fixed. Because of the traditional notion of hometown, most Chinese settlements are stable and not easily relocated. Therefore, people in their circle of friends often do not change for decades, and "the turn of the ages(世代之交)" is not uncommon. The West differs. Western circle of friends is dynamic. According to Pierre Bourdieu, a famous French sociologist, circles are often necessary tools for expanding the horizon of social research from the traditional to the developed one (cited in Zhang Boyu2008:134). Influenced by individualism, Westerners regard people as independent individuals and often participate in activities as individuals, so the difference between insiders and outsiders is less obvious.

\subsection{Communication Obstacles Caused by Cultural Differences}

Cultural differences are the source of barriers to communication. Chinese culture and western culture are two fundamentally different cultural systems in world culture. Their unique ideologies, values, ways of thinking and 
customs vary widely. The specific cultural differences mentioned above affect people-to-people exchanges in many ways. This paper mainly discusses two aspects of communication barriers caused by culture differences. They are cultural vacancies and pragmatic failures.

\subsubsection{Cultural Vacancies}

Make up for the cultural vacancy is an important part of promoting intercultural communication. In the 1950s, American linguist Hockett first discovered the vacancy. He compared the grammatical patterns of the two languages and proposed "random holes in patterns" (Hockett1954). The cultural vacancy caused by cultural differences in interpretation includes a number of reasons, which are mainly represented by semantic zero. Semantic zero is also called cultural load words, that is, the cultural connotation of vocabulary in the source language does not correspond to the target language. Without enough knowledge of another culture, interpreters cannot truly understand the speaker's intentions and the deeper implications of the discourse.

Vocabulary interpretation with their own national cultural identity tends to result in semantic zero because they are well known locally and little known abroad. For instance, there is a saying in Du Fu's poem-“桃花一 簇开无主, 可爱深红爱浅红”, which contains the unique Chinese cultural background. In this sentence, the corresponding words in English are very difficult to be found and expressed. Actually, “桃花” is native to China, although later widely cultivated in temperate regions of the world, it is still not common in the West. So in English, translation for“桃花” is “peach blossom”. Unlike roses or violets having a direct meaning of the word, it is a combination of two words. The same example is “梅花” ( plum blossom). “Plum” means“梅子，李子” in Chinese, not a direct substitute. In addition, temples are Buddhist shrines, whereas Westerner believes in Christian. In the West, there are no temples but only churches representing Western religions. Semantic zero also exists in proverbs. Take“班门弄斧 for example, it is from the Chinese allusions. “班” refers to the ancient Chinese carpenter ancestor 鲁班. Since there is no correspondence in English, we can only translate it into "teach fish to swim" according to its metaphor. Another example is from Wu Yingjian, who says that Chinese food culture has a long history and sophisticated culinary skills. Compared with Chinese cooking methods, English vocabulary in the cooking field is limited, so semantic zero appears in the process of Chinese-English interpretation (Wu2017: 57). The colour words deeply influenced by local cultural thoughts also appeared in the vacancy phenomenon. For example, there are a lot of rooms in the White House (白宫). The Green House is an informal reception room, the Blue House is the Banquet Hall and VIP reception room, and the Red House is the most popular room for The First Lady. If these Houses are interpreted directly into“绿房子, 红房子, 蓝房子”, it would be difficult for people to comprehend its real meaning.

\subsubsection{Pragmatic Failures}

Pragmatics is the subject which studies on how to use the language properly and how to comprehend the language (He Ziran\& Chen Xinren2004). Pragmatic failures do not mean performance errors, but a mistake made by both parties when they speak due to improper communication methods or different habits of expression. Pragmatic failures are in many cases caused by the cultural differences between different nations. In this part, I would choose one of them to research on. Jenny Thomas divided it into two sorts: "pragma-linguistic failures" and "socio-pragmatic failures" (Thomas1983:91-112). At interpreting activities, pragma-linguistic failures are expressed as follows: equating Chinese and English words; applying the expression structure of Chinese mechanically or misusing the expression structure of English. Socio-pragmatic failures refer to mistakes on language expressions that emerge without understanding or neglecting the cultural background of communicative objects. If interpreters do not understand the cultural differences between the two parties, it is 
easy to affect the quality of communication.

Applying Chinese-speaking expressions is typical of pragma-linguistic failures. For example, influenced by traditional Chinese Confucian culture, Chinese is modest and tactful in expression, so they prefer to use ambiguous words when it comes to communicating with people, such as "roughly, probably, maybe" and so on. Nevertheless, Westerners' ways of speaking have always been simple and direct. These vague terms in their views are extremely hypocritical, or even disrespectful. In addition, when the Chinese people were praised, the first reaction was to deny and then repay. Westerners, however, do not understand this practice. They are accustomed to saying thanks directly. Misusing phatic communion is typical of socio-pragmatic failures. For example, Chinese people routinely greet as they meet acquaintances, "Have you eaten yet?" or "Where are you going?" For the former, Westerners would expect that they were invited to have dinner together. For the latter, Westerners would think speakers are exploring their privacy. Since there are many pragmatic failures caused by cultural differences, interpreters should learn and understand the differences in pragmatic rules between Chinese and English and truly become a "bilingual people".

\section{Coping Strategies ofCommunication Barriers in Interpreting}

As we all know, the ultimate goal of analyzing a problem is to solve the problem. Cultural differences are the source of barriers to communication. After understanding the main communication barriers caused by cultural differences, we should make the right remedy and put forward a set of effective measures to deal with them. The next part focuses on coping strategies for communication barriers.

\subsection{Domestication and Foreignization}

In the early 19th century, the German philosopher Schleiermacher mentioned two different ways of translation in a lecture.

"There are only two. Either the translator leaves the author in peace as much as possible, and moves the reader toward him, or the translator leaves the reader in peace as much as possible, and moves the author toward him."(cited in Venuti1995:19).

What he said inspired American scholar L. Venuti to raise the issue of domestication (naturalization) and foreignization (alienation) strategies in translation in the 1990s. In his view, naturalization is the translation strategy for the translator to minimize the "strangeness" in the foreign text in order to create a transparent and smooth translation, and alienation refers to the translation strategy that translators preserve some "strangeness" in the original works so as to deliberately influence the norms of the target culture(ibid.: 20).

Domestication is a translating strategy that moves readers closer. That is, to desalinate the exotic features of the language, to localize it in order to conform to the reader's customary expression.

"Domestication is a term used by Venuti to describe the translation strategy in which a transparent, fluent style is adopted in order to minimize the strangeness of the foreign text for Target Language readers."(Shuttleworth\& Cowie2004: 43-44).

Foreignization is a translating strategy to the author, in other words, a translating strategy trying to truly present the content of the original as well as the author's language expression, and to maximize the preservation of the cultural characteristics of the original so that it is consistent with the source language of expression. 


\section{IRA-International Joumal of Education छ Multidisciplinary Studies}

"Foreignization is a term used by Venuti to designate the type of translation in which a Target Text is produced which deliberately breaks target conventions by retaining something of the foreignness of the original."(ibid.: 59)

For a long time, researchers have different views on the two concepts of "alienation and naturalization" and "literal translation and free translation". Many researchers believe that literal translation and free translation are equivalent to alienation and naturalization. In fact, alienation and naturalization belong to translation strategies, while literal translation and free translation are specific methods. Sun Huijun (2003: 60-64) once proposed that alienation and naturalization are more principled, involving a wider scope than literal translation and free translation. Actually, they are extricated from purely discursive language discussions and look at translation issues in a cultural context.

\subsection{Flexible Use of Interpreting Methods}

Translation can be divided into two major categories: written translation and interpretation. Interpretation is different from written translation. More specifically, interpreting activity is an instant on-site translating activity, which cannot fully apply Yan Fu's three principles of translating - "Faithfulness, Expressiveness, and Elegance".As Mei Deming explains, the characteristics of interpreting "reality", "scene" and "time limit" determine that the standard of interpretation is different from the standard of written translation. The basic criterion for measuring the quality of interpretation should be "accuracy and fluency" (Mei Deming2006). But in order to improve the quality of translation, the most basic approach is to make good use of interpreting skills. Only when interpreters are proficient in interpreting skills can they promote their own capability of interpretation as well as enhance the efficiency of interpreting activities in the process of cultural exchanges between China and the West. Take the speech of Chairman Xi at a large-scale meeting between leaders of BRICS countries in Xiamen as an example一中国古人说: “交得其道, 千里同好, 固于胶漆, 坚于金石。” 金砖合作之所以得到快速发展, 关键在于找准了合作之道。 The translation is as follows: As an ancient Chinese saying goes, “A partnership forged with the right approach defies geographical distance; it is thicker than glue and stronger than metal and stone." We owe the rapid development of BRICS cooperation to our adoption of the right approach. This sentence uses an interpreting method combining literal translation and free translation. Thus, Chinese ancient proverbs are flexibly presented. In the following part, we will discuss several specific ways of interpretation.

\subsubsection{Literal Interpretation}

Literal interpretation is a common kind of translation method under the guidance of alienation strategies. When the original works and the translations have the same words in the literal and associative sense, the literal interpretation method allows the translations to be understood more easily without losing the cultural characteristic of the original. For example, “他是一只狡猾的老狐狸” can be literally translated as “He is a crafty old fox", because “fox" symbolizes “cunning” both in Chinese and Western cultures. “如鱼得水” to “feel just like fish in wave" also shows the way of literal interpretation. Words like rhetoric can also use literal interpretation method to reflect the original unique cultural information and aesthetic value. For example, when the interpreter is introducing a classic work of Chinese literature to foreign friends, there is a sentence in Cao Xueqin'sDream of Red Mansions－宝钗笑道: “不用问，狗嘴里还有象牙不成? ”The translation from Yang Xianyi is as follows - "I do not have to ask," retorted Pao-chai, "one doesn't 't expect ivory from a dog's mouth." The sentence shows a typical use of the literal method. If the interpreter interprets this sentence literally like this way, the original cultural characteristics would be remained. However, it is noted that, literal interpretation is not 
a mechanical interpretation of verbatim. Chinese and English have different structures, so there is no need to rigidly adhere to the word-for-word principle. To some extent, a literal interpretation not only preserves the original features, but also allows readers to gradually accept the original style and the way of expression. In fact, literal interpretation and free interpretation are not two opposing concepts, but interrelated and complementary. Through the following research, we will find that in the process of interpretation, we cannot completely separate these two methods. It is for this reason that there are more and more examples of smooth exchanges in interpreting activities through the flexible application of interpreting methods.

Take a sentence coming from Chairman Xi's address at the sixth meeting among BRICS leaders for example-“我们应该坚持共赢精神, 在追求本国利益的同时兼顾别国利益, 做到惠本国、利天下, 推动 走出一条大国合作共赢、良性互动的路子。”It can be translated as-“We need to keep the spirit of win-win progress to accommodate other countries' interests while pursuing our own, bring benefits to our own countries and the world as a whole, and explore a path of win-win cooperation and positive interaction among major countries." The interpreter flexibly uses literal interpreting methods to express China's determination to pursue win-win cooperation and common development.

\subsubsection{Free Interpretation}

Free interpretation is another common kind of translation method under the guidance of naturalization strategy. While preserving the original content, it is not limited to the original form. In the event of a vacancy, free interpretation can be used. For example, “干杯” should be literally translated into "Dry up your glasses or Bottoms up with guilty pleasures". But there is no such use in English, so it is ok to translate into "Cheers" of similar meaning. Proverbs can also use free interpretation. For example, “指鹿为马” is a historical allusion in China, which is difficult for Westerners to understand if translated into "call a stag a horse". However the translation of “willful misrepresentation" retains the meaning of the original word. Similarly, “守株待兔” is more appropriate to be translated into "waiting for gains without pains". During the interpreting process of English into Chinese, it is not appropriate to equal “White Christmas/a white winter” with“白色圣诞节”, but translation as “瑞雪兆丰年” fully demonstrates the meaning of Chinese culture. When interpreters are required to interpret Chinese traditional masterworks to people from other countries, free interpreting method is a good choice. There is an example in the field of literary translation. Hawkes commonly used translation methods to achieve the purpose of naturalization, he believed that "The Dream of Red Chamber" as a translation of 《红楼梦》 prevailing in the West was wrong, because it may easily lead to misunderstanding. He proposed two translations

- "The Story of the Stone" and "The Dream of Golden Days" (Hawkes1973), which preserved the oriental flavour while making western readers more receptive. We all know there is also a famous version of 《红楼梦》 in China, that is-“A Dream of Red Mansions", a translation of Yang Xianyi and his wife. Below are the two English versions:

Look at the following instance:

Example: 谋事在人, 成事在天。

Man proposition, Heaven disposes of. (Yang \& Yang1994)

Man proposes God, disposes. (Hawkes1973)

Different ethnic groups have different religious beliefs. As classic Chinese literature, A Dream of Red Mansions contains Buddhism and Taoism. Mr Yang translated “天” into "heaven”, preserving the original religious flavour. And Hawkes directly quoted the British proverb. "Heaven" is translated as God, which converted the original text of the Buddhist colour into a Christian colour, more for Western readers to accept. 


\subsubsection{Amplification}

Amplification is also called literal interpretation combined with paraphrasing. We can use amplification to explain words when the translation of the words does not directly correspond to the meaning of words in the original work. For example, in order to accurately express its rhetorical meaning, the “黄袍加身” in Chinese ancient words can be dealt with in this way of translating_- "be draped with the Imperial yellow robe by one's supporters - be acclaimed emperor." Wang Lei proposed that it is a good choice to validate the phase through the amplification method (Wang2017: 74). There is an example cited by Chen Hongwei. That is—“这对年轻夫 妇并不相配, 一个是西施, 一个是张飞”(Chen\& Li 2013). We all know that Xi Shi and Zhang Fei are historical figures in Chinese classical literature, given the cultural background is not the same, the amplification method should be used to briefly summarize the two representative characteristics.

In addition to explaining the meaning and background of words or sentences, amplification also means complementing the sentence component. Chinese often omits the subject, While English focuses on the integrity of the sentence component, so Chinese-to-English translating activities need to add a subject. For example, when Yang Jiechi, the former Minister of Foreign Affairs, addressed the Conference on Disarmament on August 12, 2009, he quoted the famous saying of XunZi (an ancient Chinese thinker). He said that “不积跬步, 无以至 千里; 不积小流, 无以成江海”. The sentence can be translated into- “You can never make thousands of miles without piling up every single step, as the enormous ocean cannot be formed without gathering every tiny stream." Generally speaking, amplification can fully and clearly reflect the characteristics of the source language, making foreign readers not only understand what the author wants to say but also learn Chinese culture from it. Therefore, amplification is conducive to deepening the level of cultural exchange between China and the West.

\subsection{Improving Interpreters' Qualities in Intercultural Communication}

In addition to using translation skills flexibly, it is also important to enhance the interpreter's qualities of intercultural communication. According to Zhao Junfeng and Jiang Nan, for interpreters, cross-cultural awareness refers to a cognitive standard and adjustment method that they consciously or unconsciously form in intercultural communication, or it refers to the interpreter's unique way of thinking, judgment ability and sensitivity to cultural factors(Zhao\& Jiang1998: 29-31). Indeed, consciousness guides practice. If interpreters try to learn and understand Chinese and Western cultures, there will be no stumble or mistranslation in interpreting activities. There are also many on-site obstacles encountered during the course of interpretation, such as very little preparation time before interpretation, enormous pressure from the atmosphere and that the client is from a work area unfamiliar to the interpreter. All of these factors require interpreters to raise their awareness and qualities of intercultural communication and to learn a wide range of bilingual cultural knowledge to ensure an orderly interpreting process.

\subsubsection{Learning the Culture of Source Language and Target Language}

When translating foreign articles, many Chinese scholars think that translation should be loyal to the original in order to use alienation to retain the original cultural characteristics, while some people consider that translation should be more localized to the target language, so as to make it more acceptable to readers. In any case, culture is the carrier of language. In order to avoid the ineffective communication caused by mistakes in the target language, it is necessary for interpreters to do further research on both cultures. Below we will take the process of English-to-Chinese interpretation for example. During the process, English is the source language and 
Chinese is the target language. In order to learn the target language, we should follow the "never-ending learning" principle, because the Chinese is profound, which contains the meaning and knowledge that can never be learned. As a foreign language, the source language is more difficult to learn than the target language. From the perspective of values, China advocates collectivism while the West advocates individualism. As far as thinking mode, The Chinese pay attention to aesthetic feelings while the West emphasizes on logical thoughts. In terms of religious belief, China is deeply influenced by the ideas of "Buddhism, Taoism and Confucianism", yet "Christianity" is believed in the West. Therefore, interpreters in the process of learning the source language culture should mainly start from the three aspects above to fully comprehend and follow the Chinese and Western cultures. It is well-known that ancient Rome is one of the birthplaces of Western culture and Roman civilization is an important source of western civilization. So there is no wonder that many Western proverbs use “Rome" as a metaphor. Examples are as follows:1““冰冻三尺, 非一日之寒” is translated into "Rome was not built in a Day”. 2.“入乡随俗” has the same meaning with “Do in Rome as the Romans do”. 3.“三百六十行, 行 行出状元” signifies the meaning of “All roads lead to Rome”. There are many cases where the source language and the target language do not correspond. For example, "Everybody's business is nobody's business" means"三 个和尚没水吃”(religious and cultural differences); “The same knife cuts breads and fingers” means“水能载舟, 亦能覆舟”(Differences in Lifestyles). Only by thoroughly studying bilingual cultures can interpreters demonstrate their cultural confidence and cultural diversity in their interpreting activities and promote the common development of Chinese and Western cultures.

\subsubsection{Improving Interpreters' Intercultural Communication Skills}

"Interpreter" in English originates from Latin "interpret", which means middleman who is engaged in "clarification" or "interpretation" among people (Mei Deming2006). Since interpreters are intermediaries of two cultures and messengers of cultural exchange, they must have higher professionalism and rich cultural deposits. Gao Feng suggests that interpreting skills are part of the interpreter's ability as a qualified interpreter. In his words, the competence contains many aspects:

"It is composed of a variety of factors, including the ability to discern the source language, the ability to logically integrate and analyze, the ability to interpreting memories and the ability of flexible transition and accurate presentation." (Gao2017: 49-52).

Generally speaking, improvement of the interpreter's ability mainly includes the following points: grasping the characteristics and rules of interpretation of English and Chinese; possessing the ability to expel words and sentences; expressing neatly. All of these abilities are the result of an in-depth study of Chinese and Western cultures. To sum up, reserving knowledge and training practice is the core to enhance the ability. Some researchers put it that there are some conventional idioms and rich cultural allusions of various ethnic groups. In conclusion, interpreters should extensively study and constantly expand their knowledge, build a rich corpus and remember it diligently for a long time and speed up the search for target language so as to achieve better results in the interpreting process. Taking part in some interpreting activities, summing up the experience in practices will also speed up the growth of interpreters.

\section{Conclusion}

With the continuous development and deepening of the relations between countries in various fields, there are also more and more occasions that need face-to-face exchanges. As an instant translation activity, interpreting is increasingly becoming an indispensable form of diplomacy. After long-term development, translation has become more than just a linguistic symbolic conversion activity, but a model of cultural transformation. The 
translation is a behaviour of cross-cultural communication, so is interpretation. Guo Jianzhong concluded some academic names for "translation". They are called as "intercultural communication (Christiane Nord)", "intercultural cooperation (Holz-Manttari)", "acculturation(Andre Lefevere)", or "transculturation (R. Daniel Shaw)" (cited in Guo1998: 13-20). To sum up, cultural factors are always inseparable. Nowadays, many practices have proved that interpreters have taken on the role of cultural communicator, and qualified interpreters are the bridge between Chinese and Western language and culture.

In the paper, we analyze the communication obstacles arising from cultural differences in interpreting activities and explore strategies and methods to deal with them. Through the analysis of the differences in historical background, values and modes of thinking, the causes of communication barriers are summed up. Then, through the research on the cultural vacancy and pragmatic failure, we summarize the problems and challenges that Chinese and Western cultures are facing. Finally, we discuss domestication and foreignization and analyze several main interpretation methods including literal interpretation, free interpretation and supplemental interpretation/amplification. And then we put forward viewpoints on how to enhance the cross-cultural awareness of interpreters. In addition, since interpretation is a practical activity, attending interpreting activities more often is necessary to all of us. Otherwise, everything is only done on paper.

There are also some shortcomings in the paper. On the one hand, we do not fully understand some of the theoretical knowledge and does not conduct further research. Therefore, the research content still needs to be supplemented. On the other hand, the lack of practical experience in interpretation causes that there are no enough examples to prove the viewpoint in the paper. But we will continue to study, in order to enrich the content and give a piece of our own strength to help enhance the intercultural communicative awareness and competence of the interpreter. After all, making the theory put into practice is the ultimate goal of the research.

\section{References:}

[1]. Beamer, Linda and Varner, Iris. 2003. Intercultural Communication in the Global Workplace. Beijing: Tsinghua University Press.

[2]. Hawkes, David. 1973. The Story of the Stone. England \& New York: Penguin Books.

[3]. Hockett, C.F. 1954. Chinese Versus English: An Exploration of the Whorfian Theses. In Hoijer, H (ed.), Language in Culture. Chicago: University of Chicago Press.

[4]. Kirchhoff, Hella. 2002. Simultaneous Interpreting: Interdependence of Variables in the Interpreting Process, Interpreting Models and Interpreting Strategies. In Pochhacker\&Shlesinger (eds.), the Interpreting Studies Reader. New York: Routledge.

[5]. Rokeach, Milton. 1968. Believes, Values, and Attitudes. San Francisco: Jossey—Bass.

[6]. Singer, Marshall. 1971. Cultural: A Perceptual Approach. The Bridge, Occasional Paper, (11): 69-72.

[7]. Shuttleworth, Mark and Cowie, Moira. 2004. Dictionary of Translation Studies. Shanghai: Shanghai Foreign Language Education Press.

[8]. Thomas, Jenny. 1983. Cross-cultural Pragmatic Failure. Applied Linguistics, (02): 91-112.

[9]. Venuti, Lawrence. 1995.The Translator's Invisibility: A History of Translation. New York: Routledge.

[10]. Yang Xianyi and Yang Gladys.1994. A Dream of Red Mansions. Beijing: ForeignLanguage Press.

[11]. 陈宏薇, 李亚丹.2013.《新编汉英翻译教程》. 上海: 上海外语教育出版社.

[12]. 冯为兰. 2009. 议中西思维模式差异对翻译的影响.中国教师, (S2):13.

[13]. 高峰.2017. 口译过程中跨文化交际知识应用研究.吉林省教育学院学报, (02):49-52.

[14]. 郭建中.1998. 翻译中的文化因素:异化与归化.外国语(上海外国语大学学报), (02): 13-20. 
[15]. 何自然,陈新仁.2004. 《当代语用学》. 北京: 外语教学与研究出版社.

[16]. 胡文仲.1993. 试论外语教学中的跨文化交际研究.外语与外语教学, (01): 2-5+10.

[17]. 黄振宇.2001. 外交口译员的若干基本素质.青岛远洋船员学院学报, (01): 68-72.

[18]. 李星.2009. 导游口译中克服文化障碍的途径与策略.职业时空, (06): 158-159.

[19]. 李智.2014.文学作品中的中西方文化差异分析.名作欣赏, (08): 111-112+125.

[20]. 刘中宁,马玉梅.2015. 索绪尔符号理论及现代符号学的应用.产业与科技论坛, (09): 46-47.

[21]. 梅德明.2006. 《高级口译教程》.上海: 上海外语教育出版社.

[22]. 孙会军.2003. 归化与异化一一两个动态的概念. 外语研究, (04): 60-64.

[23]. 王否.2017. 跨文化交际翻译的归化与异化.现代交际, (19): 74.

[24]. 韦琳.2016.翻译中的归化和异化.开封教育学院学报, (04): 52-53.

[25]. 吴英健.2017. 英汉互译中词汇空缺现象的文化分析.成才之路, (30):57.

[26]. 姚新中.2001. 《中西方人生哲学比论》. 北京: 中国人民大学出版社.

[27]. 张博宇.2008. 试论跨文化交际中的圈子文化.中国科技财富, (12): 134.

[28]. 张燕. 2002. 文化差异对口译的影响. 外语教学, (03): 57-60.

[29]. 赵军峰,蒋楠.1998. 论口译者的跨文化意识. 中国科技翻译, (02): 29-31.

[30]. 钟鹰翔.2017. 基于跨文化背景下的英美文学翻译策略研究. 散文百家(新语文活页), (02): 15.

[31]. 钟再强.2006. 口译中处理文化因素的灵活性[J]. 漯河职业技术学院学报(综合版), (04): 63-65.

[32]. 左风䢠.2001. 环性与线性:中西文化特性比较[J].社会科学, (12): 68-72. 